\title{
IMPLEMENTASI KEBIJAKAN TENTANG PENGELOLAAN BADAN USAHA MILIK DESA LAGADING KABUPATEN SIDENRENG RAPPANG
}

\author{
${ }^{1}$ Wahyudding Muhlis, ${ }^{2)}$ Sahar \\ Fakultas IImu Sosial dan IImu Politik Universitas Muhammadiyah Sidenreng Rappang \\ wahyuddingm@gmail.com \\ saharkhan43111125@gmail.com
}

\begin{abstract}
Abstrak
Tujuan penelitian ini yaitu untuk mengetahui Implementasi Peraturan Desa Lagading Nomor 4 Tahun 2014 terhadap Pengelolaan Badan Usaha Milik Desa Di Desa Lagading Kecamatan Pitu Riase Kabupaten Sidenreng Rappang dan Faktor Yang Memengaruhi Implementasi Peraturan Desa Lagading Nomor 4 Tahun 2014 terhadap Pengelolaan Badan Usaha Milik Desa Di Desa Lagading Kecamatan Pitu Riase Kabupaten Sidenreng Rappang. Populasi 36 pengurus BUMDesa Desa Lagading. Sampel dalam penelitian ini adalah keseluruhan dari jumlah populasi yaitu 36 pengurus BUMDesa, berdasarkan teknik sampel jenuh. Jenis penelitian ini adalah deskriptif kuantitatif dengan penelitian dasar, penelitian survey dan jenis data dalam penelitian ini yaitu penelitian kuantitatif, sumber data dalam penelitian ini yaitu data primer dan data sekunder. Teknik pengumpulan data yang digunakan dalam penelitian ini adalah observasi, wawancara, kuisioner, yang digunakan yaitu analisis tabulasi frekuensi dan analisis regresi sederhana dengan bantuan program SPSS 16.0 for windows. Hasil dari Implementasi Peraturan Desa Lagading Nomor 4 Tahun 2014 terhadap Pengelolaan Badan Usaha Milik Desa di Desa Lagading Kecamatan Pitu Riase Kabupaten Sidenreng Rappang berada dalam kategori "tidak baik" dengan persentase 46,8\%, maka dapat dikatakan bahwa ada pengaruh yang signifikan antara Implementasi Peraturan Desa Lagading Nomor 4 Tahun 2014 terhadap Pengelolaan Badan Usaha Milik Desa Di Desa Lagading Kecamatan Pitu Riase Kabupaten Sidenreng Rappang, hal tersebut terbukti dari hasil analisis statistik menggunakan uji regresi linier berganda, maka diperoleh nilai $t$ hitung $=2,621>t$ tabel 1,688 dengan nilai signifikansi 0,000 < 0,05, dan Faktor Yang Memengaruhi Implementasi Peraturan Desa Lagading Nomor 4 Tahun 2014 terhadap Pengelolaan Badan Usaha Milik Desa di Desa Lagading Kecamatan Pitu Riase Kabupaten Sidenreng Rappang yaitu kondisi lingkungan $80,4 \%$ berada dalam kategori "baik" sedangkan hubungan antar organisasi $42.6 \%$, sumber daya $48,8 \%$, karakteristik dan kemampuan $56 \%$. dengan kategori "kurang baik".
\end{abstract}

Kata kunci : BUMDesa, Implementasi, Pengelolaan

\begin{abstract}
The purpose of this study is to determine the implementation of village regulations Lagading No. 4 of 2014 on the management of village-owned enterprises In the village Lagading District of Pitu Riase Sidenreng Rappang and Factors Affecting Implementation of Village Regulations Lagading No. 4 of 2014 on the management of village-owned enterprises In the village Lagading Pitu subdistrict Riase Sidenreng Rappang. The village population of 36 board BUMDesa Lagading. The sample in this research is the whole of the population that is 36 BUMDesa board, based on the engineering sample is saturated. This type of research is quantitative descriptive with basic research, survey research and the type of data in this research is quantitative research, sources of data in this study are primary data and secondary data. Data collection techniques used in this research is observation, interviews, questionnaires, were used that frequency tabulation analysis and simple regression analysis with SPSS 16.0 for Windows. Results of Implementation Lagading Village Regulations No. 4 of 2014 on the management of village-owned enterprises in the Village District of Pitu Riase Lagading Sidenreng Rappang are in the category of "no good" with a percentage of $46.8 \%$, it can be said that there is significant influence between the Implementation Regulations Lagading Village No. 4 of 2014 on the management of village-owned enterprises in the village Lagading District of Pitu Riase Sidenreng Rappang, it is evident from the results of statistical analysis using multiple linear regression, the obtained $t$ count $=2,621>t$ table 1.688 with a significance value $0,000<0,05$, and factors Affecting Implementation Lagading Village Regulations No. 4 of 2014 on the management of village-owned enterprises in the Village District of Pitu Riase Lagading Sidenreng Rappang namely environmental conditions, $80.4 \%$ are in the
\end{abstract}


p-ISSN 2302-0970

e-ISSN 2723-0201

category of "good" while $42.6 \%$ inter-organizational relationships, $48.8 \%$ of resources, characteristics and capabilities of $56 \%$. the category of "unfavorable".

Keywords: BUMDesa, Implementation, Management 


\section{A. PENDAHULUAN}

Undang-undang No.6 tahun 2014 tentang Desa dinyatakan bahwa sumber pendapatan Desa salah satunya adalah pendapatan asli desa, yang meliputi: 1) hasil usaha desa; 2) hasil kekayaan desa; 3) hasil swadaya dan partisipasi; 4) hasil gotong royong; dan 5) lain-lain. Pasal 1 ayat (2) Peraturan Menteri Dalam Negeri Nomor 4 Tahun 2015 Tentang Badan Usaha Milik Desa adalah badan usaha yang seluruh atau sebagian besar modalnya dimiliki oleh Desa melalui penyertaan secara langsung yang berasal dari kekayaan Desa yang dipisahkan guna mengelola aset, jasa pelayanan, dan usaha lainnya untuk sebesar-besarnya kesejahteraan masyarakat Desa.

Menurut (Sutoro, 2014) BUMDesa merupakan elemen dan instrumen penggerak ekonomi masyarakat desa. BUMDesa harus dipahami dan dilakukan secara maksimal. BUMDesa menjadi pusat perekenomian masyarakat desa untuk menumbuh kembangkan ekonomi lokal. Keberadaan BUMDesa adalah untuk memperkuat ekonomi raktyat desa. Hasil pengamatan awal yang saya lakukan dalam pengelolaan badan usaha milik desa yang ada di Desa Lagading, Banyaknya potensi desa yang harus dikelola untuk dijadikan usaha tidak terlalu dikelola dengan baik. Mengingat potensi perikanan, peternakan, pekebunan dan pertanian desa Lagading yang sangat berlimpah untuk mengatasi hambatan yang dirasakan oleh masyarakat.

Potensi yang dimiliki Desa Lagading salah satunya yaitu Perikanan, dengan memanfaatkan danau Lagading yang dijadikan sebagai tempat untuk mencari nafkah oleh masyarakat setempat maupun dari daerah-daerah lain dan adapun jenis ikan diantaranya ikan Mas, Nila, Lohan dan ikan gabus. Selain itu potensi yang dimiliki Desa Lagading yaitu Perkebunan merupakan salah satu mata pencaharian pokok masyarakat dimana 40\% masyarakat desa lagading berprofesi di bidang perkebunan, adapun hasil dari perkebunan yaitu Kacang tanah salah satu potensi desa yang ada di lagading, lahan yang digunakan untuk kacang tanah tersebut adalah persawahan tadah hujan dimana sawah tersebut hanya berproduksi sekali dalam satu tahun, ini disebabkan oleh air yang tidak memadai.

Desa lagading juga terletak di wilayah penggunungan hal inilah yang kemudian di manfaatkan oleh warga desa Lagading untuk beternak sapi dikarenakan pakan ternak sapi itu sendiri sudah tersedia oleh alam, rata rata warga desa memiliki ternak sapi untuk dibudidayakan sebagai sapi pedaging yang biasanya dijual pada hari Raya Idul Adha. Berdasarkan dari uraian sebelumnya maka calon peneliti dapat merumuskan judul dalam rancangan penelitian ini yaitu "Implementasi Peraturan Desa Lagading Nomor 4 Tahun 2014 Terhadap Pengelolaan Badan Usaha Milik Desa Di Desa Lagading Kecamatan Pitu Riase Kabupaten Sidenreng Rappang dengan tujuan Untuk mengetahui Implementasi Peraturan Desa Lagading Nomor 4 Tahun 2014 terhadap Pengelolaan Badan Usaha Milik Desa Di Desa Lagading Kecamatan Pitu Riase Kabupaten Sidenreng Rappang dan Untuk mengetahui faktor yang mempengaruhi Implementasi Peraturan Implementasi Peraturan Desa Lagading Nomor 4 Tahun 2014 terhadap Pengelolaan Badan Usaha Milik Desa Di Desa Lagading Kecamatan Pitu Riase Kabupaten Sidenreng Rappang.

Menurut Van Meter dan Van Horn mendefinisikan implementasi kebijakan publik sebagai tindakan-tindakan dalam keputusankeputusan sebelumnya. Tindakan-tindakan ini mencakup usaha-usaha untuk mengubah keputusan-keputusan menjadi tindakantindakan operasional dalam kurun waktu tertentu maupun dalam rangka melanjutkan usaha-usaha untuk mencapai perubahan besar dan kecil yang ditetapkan oleh keputusan-keputusan kebijakan yang dilakukan oleh organisasi publik yang diarahkan untuk mencapai tujuan-tujuan yang telah ditetapkan. Makna implementasi menurut Daniel A. Mazmanian dan Paul Sabatier sebagaimana dikutip dalam buku (Abdul Wahab, 2008), mengatakan bahwa: Implementasi adalah memahami apa yang senyatanya terjadi sesudah suatu program dinyatakan berlaku atau dirumuskan merupakan fokus perhatian implementasi kebijaksanaan yakni kejadian-kejadian dan kegiatan-kegiatan yang timbul sesudah disahkannya pedoman-pedoman kebijaksanaan Negara yang mencakup baik usaha-usaha untuk mengadministrasikannya maupun untuk menimbulkan akibat/dampak nyata pada masyarakat atau kejadiankejadian.

Menurut (Agus, 2012) "implementasi intinya adalah kegiatan untuk 
mendistribusikan keluaran kebijakan (to deliver policy output) yang dilakukan oleh para implementor kepada kelompok sasaran (target group) sebagai upaya untuk mewujudkan kebijakan". Menurut Edward (Widodo, 2010), Ada 4 indikator menentukan keberhasilan impelmentasi kebijakan yang kemudian akan di uraikan adalah Komunikasi, Sumber daya, Disposisi/Perilaku, dan Struktur Birokrasi

Menurut Pusat Kajian Dinamika Sistem Pembangunan (2007), Badan Usaha Milik Desa (BUMDesa) adalah lembaga usaha desa yang dikelola oleh masyarakat dan pemerintahan desa dalam upaya memperkuat perekonomian desa dan dibentuk berdasarkan kebutuhan dan potensi desa. Sebagai salah satu lembaga ekonomi yang beroperasi dipedesaan, BUMDesa harus memiliki perbedaan dengan lembaga ekonomi pada umumnya. Ini dimaksudkan agar keberadaan dan kinerja BUMDesa mampu memberikan kontribusi yang signifikan terhadap peningkatan kesejahteraan warga desa. Disamping itu, supaya tidak berkembang sistem usaha kapitalistis di pedesaan yang dapat mengakibatkan terganggunya nilai-nilai kehidupan bermasyarakat.

Tujuan dari BUMDesa Berdasarkan Permendesa PPDT(Pembangunan Daerah Tertinggal dan Transmigrasi) No. 4/2015 pendirian BUMDesa bertujuan untuk Meningkatkan perekonomian Desa, Mengoptimalkan aset Desa agar bermanfaat untuk kesejahteraan Desa, Meningkatkan usaha masyarakat dalam pengelolaan potensi Desa, Mengembankan rencana kerjasama usaha antar desa dan/atau dengan pihak ketiga, Menciptakan peluang dan jaringan pasar yang mendukung kebutuhan layanan umum warga, Membuka lapangan kerja, Meningkatkan kesejahteraan masyarakat melalui perbaikan pelayanan umum, pertumbuhan dan pemerataan ekonomi Desa.

1. Meningkatkan pendapatan masyarakat desa dan pendpatan asli desa.

Prinsip-prinsip pengelolaan Badan Usaha Milik Desa (BUMDesa) mengacu pada Pedoman Umum Good Corporate Governance (GCG) Indonesia Tahun 2006 dalam (Setyawan 2016) adalah Transparansi (Transparency), Akuntabilitas (accountability), Responsibilitas

(Responsibility),
Independensi (Independency),

Kewajaran dan Kesetaraan (Fairness) .

Menurut Cheema dan Rondinelli (Subarsono, 2005) ada empat indikator yang memopengaruhi kebijakan publik yaitu Kondisi lingkungan, Hubungan antar organisasi, Sumberdaya, dan Karakteristik dan kemampuan

\section{B. METODE PENELITIAN}

Adapun metode yang digunakan dalam yang digunakan dalam penelitian ini adalah metode deskriptif yaitu prosedur pemecah masalah dengan cara menggambarkan objek penelitian pada saat sekarang berdasarkan fakta-fakta sebagaimana adanya, kemudian dianalisis dan diinterpretasikan, bentuknya berupa survey dan studi pengembangan. Populasi dalam penelitian ini adalah anggota BUMDesa yang berjumlah 36 anggota di Desa Lagading Kecamatan Pitu Riase Kabupaten Sidrap, sedangkan Sampel pada penelitian ini adalah sampel jenuh yakni 36 anggota BUMDesa. Dasar pengambilan sampel jenuh ini sesuai dengan pendapat Arikunto (2006), yang mengemukakan bahwa apabila subjek kurang dari 100, maka lebih baik diambil semua, sehingga penelitiannya adalah penelitian populasi.

Teknik pengumpulan data yang digunakan adalah melalui Observasi, Wawancara, Kuisioner, sedangkan teknik analisis data yang digunakan adalah Penelitian kuantitatif analisis data merupakan kegiatan setelah data dari responden terkumpul, data yang telah terkumpul dilakukan analisis dengan bantuan program SPSS untuk windows, hasil analisis berupa statistik deskriptif, uji kualitas data, analisis deskriptif jenis data interval, dan analisis regresi linear berganda dan uji hipotesis, Uji Kualitas Data (Uji Validitas dan Reliabilitas), Instrumen Skala Pengukuran.

\section{HASIL DAN PEMBAHASAN}

Berdasarkan coefficients hasil olahan data, maka model regresi yang digunakan dalam penelitian ini untuk mengukur implemetasi peraturan desa nomor 4 tahun 2014 terhadap pengelolaan BUMDesa di Desa Lagading Kecamatan Pitu Riase Kabupaten Sidenreng Rappang. Dapat dianalisa berdasarkan coefficients sebagai berikut.

$Y=a+b X$ atau $17,337+0,172 X$

Dari fungsi diatas maka dapat dijelaskan : 
1) Jika variabel implementasi $(X)$ berubah, maka Pengelolaan BUMDesa ( $Y$ ) juga akan berubah tanda positif menunjukkan perubahan yang searah. Apabila implementasi Peraturan Desa Nomor 4 tahun 2014 meningkat maka pengelolaan BUMDesa juga meningkat dengan coefficient sebesar 0,172. Dan sebaliknya, jika implementasi peraturan desa nomor 4 tahun 2014 menurun maka maka pengelolaan BUMDesa Di desa lagading kecamatan Pitu Riase Kabupateb Sidenreng Rappang juga akan menurun dengan coefficients sebesar 0,172.

2) Nilai konstanta sebesar 17.337 menunjukkan bahwa jika variabel implementasi peraturan desa Lagading (X) konstan, maka pengelolaan BUMDesa (Y) masih bersifat positif.

Tanggapan responden tentang faktor yang memengaruhi implementasi peraturan desa desa Lagading di Desa lagading Kecamatan Pitu Riase Kabupaten Sidenreng Rappang. Dari keempat indikator antara lain Kondisi lingkungan, hubungan antar organisasi, sumber daya, dan karakteristikdan kemampuan diperoleh ratarata persentase sebesar $56,95 \%$ yang termasuk kategori kurang baik.

\section{KESIMPULAN}

Berdasarkan hasil penelitian yang telah diuraikan pada bab di atas, maka dapat disimpulkan bahwa:

1. Implementasi Peraturan Desa Lagading Nomor 4 Tahun 2014 Terhadap Pengelolaan BUMDes di Desa Lagading Kecamatan Pitu Riase Kabupaten Sidenrang Rappang adalah 46,8\% dari yang dihasilkan dan diketahui nilai t hitung $=2,621>t$ tabel 1,688 dengan nilai signifikansi $0,000<0,05$ maka dapat dikatakan ada pengaruh yang signifikan antara Variabel Implementasi Peraturan Desa Lagading Nomor 4 Tahun 2014 Terhadap Pengelolaan BUMDes.

2. Faktor yang memengaruhi Implementasi Peraturan Desa Lagading Nomor 4 tahn 2014 Terhadap Pengelolaan BUMDes yaitu kondisi lingkungan $80,4 \%$ berada dalam kategori "baik" sedangkan hubungan antar organisasi $42.6 \%$, sumber daya $48,8 \%$, karakteristik dan kemampuan $56 \%$ berada dalam kategori "kurang baik".

\section{E. REFERENSI}

Abdul Wahab, S. (2008). Analisis Kebijakan dari Formulasi ke Implementasi Kebijakan Negara. Jakarta: Bumi Aksara.

Agus, E. P. (2012). Implementasi Kebijakan Publik, Konsep dan Aplikasinya di Indonesia. Yogyakarta: Gava Media.

Subarsono, A. (2005). Analisis Kebijakan Publik, Konsep, Teori dan Aplikasi. Yogyakarta: Pustaka Pelajar.

Sutoro, E. D. (2014). Desa Membangun Indonesia. Yogyakarta: FPPD.

Widodo, J. (2010). Metode Penelitian Sosial. Bandung: PT. Remaja Rosda Karya. 